\title{
Beş Yaş Çocuklarının Cinsiyet Kalıp Yargı Düzeyleri ve Evdeki Cinsiyet Rollerine İlişkin Görüşleri ${ }^{1}$ iD Selda ATA DOĞAN
}

Hacettepe Üniversitesi, Eğitim Fakültesi, Temel Eğitim Bölümü slda.ata@gmail.com

(iD) Nevra ATIŞ AKYOL

Hacettepe Üniversitesi, Eğitim Fakültesi, Temel Eğitim Bölümü nevrarven@gmail.com

Neslihan GÜNEY KARAMAN

Ankara Üniversitesi, Eğitim Fakültesi, Eğitim Bilimleri Bölümü neslihanguney@gmail.com

Gönderilme Tarihi: 27/07/2018

Kabul Tarihi: $30 / 11 / 2018$

Yayınlanma Tarihi: 30/11/2018

DOI: $10.30855 /$ gjes.2018.04.03.004

\begin{tabular}{l}
\hline Makale Bilgiler \\
\hline Anahtar \\
Kelimeler: \\
Toplumsal \\
cinsiyet, \\
Cinsiyet kalıp \\
yarg1, \\
Cinsiyet rolleri
\end{tabular}

ÖZET

İnsanların en görülebilir ve en temel sinıflama ayrımı olarak nitelendirilebilen cinsiyet kavramı kişinin sosyal hayatının etkisiyle biyolojik cinsiyet ayrımından toplumsal cinsiyet ayrımına doğru farklılaşarak şekillenmektedir. Toplumsal cinsiyetlere ait roller erken çocukluk döneminde öğrenilerek, çocuklardaki cinsiyet kalıp yargıların temeli atılmaya başlanmaktadır. $\mathrm{Bu}$ roller, çocukların ilk toplumsallaşma ortamı olan ailede içselleştirilmekte ve zaman içerisinde kazanılmaktadırlar. Bu araştırmada beş yaş çocuklarının cinsiyet kalıp yargı düzeylerinin belirlenmesi ve çocukların evdeki cinsiyet rollerine ilişkin görüşlerinin incelenmesi amaçlanmıştır. Araştırmada karma yöntem kullanılmıştır. Çocukların kendi evlerinde gözlemlediği toplumsal cinsiyet rollerine yönelik yaşantılarının, annenin iş hayatında aktif olarak yer alıp almamasına göre değişebileceği göz önüne alınarak araştırma grubu belirlenmiştir. Bu nedenle, amaçlı örneklem yöntemlerinden benzeşik örnekleme yöntemi kullanılarak, annesi çalışmakta olan 8 erkek ve 8 kız; annesi çalışmayan 8 erkek ve $8 \mathrm{k}$ z çocuğu olmak üzere toplam 32 beş yaş çocuğu araştırmaya dâhil edilmiştir. Veri toplama aracı olarak, araştırmacılar tarafından hazırlanan "Ebeveyn Toplumsal Cinsiyet Gösterge Resimleri", "Yarı Yapılandırılmış Görüşme Soruları", "Ebeveyn Demografik Bilgi Formu" ve Şirvanlı Özen (1992) tarafından uyarlaması yapılan "Cinsiyet Kalıp Yargi Ölçeği" kullanılmıştır. Araştırmadan elde edilen veriler tümevarımsal betimsel analiz ve çapraz tablo analizi ile analiz edilmiştir. Araştırma sonucunda çocuklardan 27'sinin cinsiyet kalıp yargısının olduğu ve bu kalıp yargıların bazı boyutlarda evdeki toplumsal cinsiyet rolleriyle ilişkili olduğu bulunmuştur.

\footnotetext{
${ }^{1}$ Bu çalışmanın bir kısmı 02-05 Mayıs 2018 tarihleri arasında Akdeniz Üniversitesi’nde düzenlenen $\mathrm{V}^{\text {th }}$ International Eurasian Educational Research Congress'te 'Beş yaşındaki çocukların evdeki cinsiyet rollerine ilişkin görüşleri' başlı̆̆ ile sunulmuştur.

Ata Doğan, S., Atış Akyol, N., \& Güney Karaman, N. (2018 Beş Yaş çocuklarının cinsiyet kalıp yargı düzeyleri ve evdeki cinsiyet rollerine ilişkin görüşleri. Gazi Eğitim Bilimleri Dergisi, 4(3), 5365. DOI: https://dx.doi.org/10.30855/gjes.2018.04.03.004.
} 


\section{Opinions of 5-year-olds on Level of Gender Stereotype and Gender Roles at Home}

\begin{tabular}{ll}
\hline \hline Article Info & ABSTRACT \\
\hline Keywords: & $\begin{array}{l}\text { Sex concept, described as the most visible and basic classification of } \\
\text { people, shaped by biological sex and gender differences in the influence } \\
\text { Gender role, }\end{array}$ \\
of one's social life. Genders are learned in early childhood years. These \\
learnings are thought to lay the foundations for gender stereotypes in \\
children. The sex roles are internalized in the family environment which \\
is the first socialization environment of children and children acquire \\
these roles over time. This study is aimed to reveal children's gender \\
stereotype levels and views of children on parents' gender roles at \\
home. Mixed method was used in this research. A research group has \\
been identified by considering that the experiences of sex roles observed \\
by children in their own homes may vary according to whether their \\
mother is actively involved in business life. Homogeneous sampling \\
was benefited, and research group is composed of 32 five years-old \\
children (eight boys and eight girls with employed mothers, eight boys \\
and eight girls with unemployed mothers). Data collected through" \\
Parent's Gender Indicator Pictures"," Semi-structured Interview \\
Questions", "Parent Demographic Information Form" and "Sex \\
$\begin{array}{l}\text { Stereotype Measure Scale". Data from the study were analyzed by } \\
\text { inductive descriptive analysis and cross-tabulation analysis. As a result } \\
\text { of the research, 27 of children have gender stereotypes and these are } \\
\text { related to gender roles at home in some dimensions. }\end{array}$ \\
\hline
\end{tabular}

\section{Gíriş}

İnsanlar daha doğmadan önce bir sınıflandırmayla karşı karşıya kalırlar. Tüm dünyada var olan bu sınıflandırma cinsiyet sınıflandırmasıdır. İnsanların en görünür, en yaygın ve en basit sinıflandırması olarak tanımlanabilen cinsiyet kavramı biyolojik olarak kadın veya erkek olmak şeklinde ifade edilmektedir Bu kavram sosyal hayatın etkisi ile biyolojik cinsiyet ve cinsiyet farklılıkları ile şekillenebilir ve farklılaşabilir. Sosyo-kültürel değerler kapsamında ortaya çıkan cinsiyete yönelik algılar, toplumsal cinsiyet kavramını ortaya çıkarmaktadır. Toplumsal cinsiyet, bireyi kadınsı ya da erkeksi olarak ayırt eden psiko-sosyal özellikler olarak tanımlanmaktadır. Ayrıca toplumsal cinsiyet, kültürel bir içeriği karşılamakta ve genellikle bireylerin biyolojik yapısı ile alakalı olan psikolojik özellikleri de içermektedir (Dökmen, 2012). Yani kültüre, yere ve zamana göre değişiklik gösterebilen fakat kadından sırf kadın doğduğu için, erkekten de sırf erkek doğduğu için beklenen davranışlar bulunmaktadır. Toplumsal cinsiyet, bireyin cinsiyetinden dolayı toplum tarafından nasıl algılandığı, kadın ve erkeğin nasıl görünmesinden, nasıl hissetmesi gerektiğine kadar birçok birleşeni kapsamaktadır (Helman, 1990; Akt. Yağan Güder ve Güler Yıldız, 2016). İnsanlar dişi ve erkek cinsiyeti ile doğarlar fakat yetiştikleri toplumun cinsiyetlerine özgü beklediği roller kapsamında kız veya erkek çocuk olmayı öğrenerek büyürler. Çocuk öncelikle ilk toplumsallaşma ortamı olan ailede toplumsal cinsiyete yönelik rolleri içselleştirmekte ve zamanla bu rolleri kazanmaktadır (Terzioğlu ve Taşkın, 2008). Alan yazında cinsiyet, biyolojik cinsiyet, cinsiyet rolleri, toplum cinsiyet gibi farklı kavramlar yer almaktadır. Erken çocukluk döneminde belirginleşen toplumsal cinsiyet kavramı her ne kadar çocuk için cinsiyet kavramından çok da farklı olmasa da alan yazında farklı kavramlar olarak ele alınmaktadır. 
Biyolojik cinsiyet ve toplumsal cinsiyet arasındaki fark; biyolojik cinsiyet doğumdan gelen hormonlar ve fiziksel farklılıkların yansıması olarak tanımlanırken; toplumsal cinsiyet bireylerin yaşamlarını şekillendirmede etkin rol alan seçim, davranış, tutum ve sorumluluklarını belirleme hususunda toplumsal beklentiler olarak tanımlanmaktadır. Biyolojik kökenli kuramlara göre, biyolojik cinsiyet, toplumsal cinsiyet rollerinin belirlenmesinde etkendir. Kadınlar çocuk doğurma yetisine sahip olduklarından, yüzyıllar boyunca toplumsal cinsiyet rolleri de bu yönde şekillenmiş ve kadınlar çocuk bakımı ile ilgilenirken erkekler de çocuk doğurma yetisine sahip olmadıklarından ailelere kaynak sağlamak amacı ile sorumluluklar üstlenmişlerdir (Güldü ve Ersoy-Kart, 2009). Fakat günümüzde doğum kontrol yöntemleri geliştiği ve fiziksel güce dayalı kaynak sağlama sorumluluğu azaldığı için, biyolojik kökenli rol dağılımları anlamını kaybetmeye başlamasına rağmen, bu çağlar öncesinden kalan düşünceler, herhangi bir mantıksal dayanak olmadan toplumları şekillendirmeye devam etmektedir (Birey ve Beyidoğlu Önen, 2013).

Sosyal rol kuramı ise sosyal ve siyasal davranış ve tutumlarda gözlemlenen kadın ve erkek farklılıklarının, kadın ve erkeklerin farklı roller üstlenmesinden kaynaklandığını ileri sürmektedir. Bireyler başarılı rol performansları gösterebilmek için doğuştan getirdikleri ve zamanla edindikleri özellikleri birleştirerek cinsiyete özgü toplumsal rollere bürünmektedirler Günümüzde bu düşünce kısmen değişse de halen küçük yaşlardan itibaren kadınlara yemek pişirmek gibi ev işleri ile ilgili beceriler öğretilirken, erkeklere ekonomik anlamda kullanabilecekleri beceriler öğretilmektedir. Bu toplumsal rol dağılımları anne-baba, arkadaş gibi bireylerarası ilişkilerle de desteklenerek süreklilik kazanmaktadır (Güldü ve Ersoy-Kant, 2009). Albert Bandura'nın Sosyal Öğrenme Kuramı'nda çocuk yeni davranışları çevresindeki kişileri gözlemleyerek taklit etmektedir. Çocukların gördükleri modeller başarılı, güçlü ya da popüler ise ve çocuk bu kişiyi ya da kişileri taklit ettiğinde ödüllendiriliyorsa bu davranışa devam eder. Bu şekilde erkek çocuklar babasını gözlemleyerek erkek gibi olmayı, kız çocukları da annesini gözlemleyerek kadın gibi olmayı öğrenmektedir (Yeşilyaprak, 2015). Böylece çocuklar ebeveynlerinin cinsiyet rollerini öğrenmekte, anne babanın davranışları çocuğa model olmaktadır. Benzer şekilde Freud'un Psikoseksüel Kuramı'nda fallik dönemde bulunan çocukların Oedipus ve Elektra komplekslerinin ve özdeşim mekanizmaların sonucunda cinsiyet kimliklerinin şekillenerek, kız çocuklarının zaman içerisinde anne ile özdeşim kurduğu, erkek çocuklarının ise baba ile özdeşim kurarak babayı taklit etmeye başladığı belirtilmektedir (Berk, 2012). Hem cinsteki ebeveyni ile özdeşim kuran çocuk hem cinsi ile aynı cinsiyet kimliğini kazanmaktadır.

Çocuğun toplumsal çevresi, aynı zamanda çocuğun kadın ve erkekler için neyin uygun ve karakteristik olduğu ile ilgili bilgileri sınıflandırmasına yarayan cinsiyet şemalarının oluşmasına da yardım etmektedir. Sosyal cinsiyet şema kuramına göre cinsiyetleri ayrıştırma, toplumun kadınsı ve erkeksi özellikleri tanımlamasına dayanır (Dökmen, 2012). Toplumdaki kadınsılık ve erkeklik tanımları bireylerin cinsiyet şemasını oluşturmaktadır. Dört yaş ve altı çocukların, beş yaş ve üstü çocuklara göre verilen cinsiyet şema görüntülerine daha fazla inandığı ve güvendiği bilinmektedir. Bunun nedeni beş yaş üstü çocukların cinsiyet rollerine ilişkin şemalarının tamamlanmış olması ve bilgilerin değişmezliğinin korunmasıdır (Bayramoğlu, 2015). Genel olarak beş yaşa kadar şekillenmiş olan cinsiyet rolleri, çocuğun çevresi ile girdiği etkileşimler ile genellenmeye ya da değişmeye doğru yol alacaktır.

Yaşamın ilk yıllarında çocukta oluşmaya başlayan cinsiyet rol algıları, kalıp yargılar ve cinsiyete dayalı eşitsizlik algısı ile pekiştirildiğinde, bireylerin tüm yaşamını etkileyecek cinsiyet kimliği algısına dönüşmektedir (Can ve arkadaşları, 2012; Akt. Bayramoğlu, 2015). Çocukların 
cinsel rol gelişimlerinin önem kazandığı okul öncesi dönemde mantıksal düşünme henüz oluşmadığı için, çocuklar sınırlı deneyimleri ile kalıp yargılar geliştirmektedirler. Anne babalar bu yargıların gelişmesinde çocuğun çevresindeki ilk modellerdir. Ankara' da çocuk yuvalarında kalan ve ailesi ile birlikte yaşayan 7-11 yaşlarındaki çocuklarda cinsiyet rolleri ve cinsiyet özellikleri kalıp yargı gelişiminin saptanmasının ve bu kalıp yargıların kazanılmasında bazı değişkenlerin etkisinin incelendiği araştırma sonucunda korunmaya muhtaç çocuklarla ailesiyle birlikte yaşayan çocuklar arasında cinsiyet kalıp yargılarının gelişimi açısından önemli farklılıklar olduğu saptanmıştır (Baran, 1995). Yapılan bir başka araştırma sonucuna göre okul öncesi dönemdeki 5 yaş çocuklarında cinsiyete dayalı yerleşik kalıp yargıların var olduğu tespit edilmiştir (Bayramoğlu, 2015). Çocuğun çevresindeki geleneksel aile yapılarının etkisi bu kalıp yargıların oluşumunda üzerinde düşünülmesi gereken bir konudur.

Geleneksel olarak toplumda çocuk bakımı anneye yüklenen bir roldür. Geleneksel aile yapısında erkekler tamir, bahçe bakımı gibi işleri yaparken, kadınlar kendilerine verilen yemek pişirme, bulaşık yıkama ve ev temizliği gibi işleri yapmaktadırlar (Şafak, Çopur, Özkan, 2006). Kadının iş yaşamına aktif katılımının artması ile birlikte ev işlerindeki sorumluluğunun azalmış olması gerektiği düşünülürken, Türkiye İstatistik Kurumu (TUİK) tarafından (2014-2015) cinsiyet ve çalışma durumuna göre kişi başına düşen ortalama faaliyet süresi rapor sonucuna göre, çalışmaya katılan 15 yaş üstü çalışan kadınların hane halkı ve aile bakımına günlük harcadığ 1 süre 3 saat 31 dakika iken, çalışan erkeklerin bu faaliyetlere ayırdığı sürenin 46 dakika olduğu tespit edilmiştir. Yine TUIK (2016)'in hanelerdeki işlerden genellikle sorumlu olan kişiler ile ilgili yapmış olduğu araştırmada yemek yapma, çamaşır yıkama, sofra kurup kaldırma, bulaşık yıkama gibi ev işlerinin büyük çoğunlukla kadınlar tarafından yapıldığı, tamir işleri, badana boya, fatura ödeme gibi işlerin erkekler tarafından yapıldığı sonucu ortaya konmuştur. Küçük yaştaki çocuklar ebeveynlerini gözlemleyerek ve model alarak öğrendikleri için evdeki görev dağılımından etkilenmektedirler. İlköğretim öğrencilerinin toplumsal cinsiyet algılarını konu alan araştırma sonucunda araştırmaya katılan çocukların toplumsal cinsiyet ile ilgili algılarının geleneksel kadın erkek rollerine paralellik gösterdiği saptanmıştır. Anne çalışıyor olsa da annenin görevinin ev işleri ve yemek yapmak olduğunu, babanın ise gazete okumak ya da televizyon seyretmek gibi davranışlar sergilediği tespit edilmiştir (Gümüşoğlu, 2004). Bu bulgulara paralel olarak Cinsiyet Eşitlik Ölçeği'nin kullanıldığı Inglehart ve Norris (2003)'ün araştırmasında Türkiye cinsiyet kalıp yargılarında 60 ülke arasında 48 'inci sırada yer almaktadır (Akt. Esmer, 2012). Bu veri hem Türkiye de aile yaşam tarzlarının toplumsal cinsiyet kalıp yargılarıyla sürdüğünü gösteren bir bilgi olduğu için hem de gelecek nesiller için bu yanlış örneklerin görünür kılındığını gösteren bir bilgi olduğu için son derece önemlidir.

Gelişimsel bakış açısında, çocukların cinsiyet kalıp yargılarının beş yaşında şekillendiği bilinmektedir (Martin ve Ruble, 2004). Tüm bu bilgiler ışı̆̆ında, beş yaş çocuklarında gelişen toplumsal cinsiyet kalıp yargılarının ülkemizde var olan geleneksel aile ev yaşantısı işleyişi açısından değerlendirilmesi önemlidir.

$\mathrm{Bu}$ araştırmada beş yaş çocuklarının bakışaçılarına göre, ebeveynlerinin evdeki toplumsal cinsiyet rollerinin incelenmesi amaçlanmıştır. Bu amaç doğrultusunda aşağıda belirtilen alt amaçlar belirlenmiştir:

1- Anne çalışma durumuna göre çocukların ebeveynlerine ilişkin toplumsal cinsiyet kalıp yargı gösterge düzeyleri nasıldır?

2- Cinsiyete göre çocukların ebeveynlerine ilişkin toplumsal cinsiyet kalıp yargıları nasildir? 
3- Anne çalışma durumuna göre çocukların toplumsal cinsiyet kalıp yargıları nasıldır?

4- Cinsiyete göre çocukların toplumsal cinsiyet kalıp yargıları nasıldır?

5- Çocukların cinsiyet kalıp yargı puanlarına göre ebeveynlerine ilişkin toplumsal cinsiyet kalıp yargıları nasıldır? nelerdir?

6- Çocukların cinsiyet kalıp yargı puanlarına göre ev işlerini kimin yaptığına dair görüşleri

\section{YÖNTEM}

$\mathrm{Bu}$ çalışma, karma yöntem araştırmalarından yakınsayan paralel desende planlanmıştır. Karma yöntem araştırması; nitel ve nicel araştırma yöntemlerinin birlikte kullanılarak araştırmacıya derinlemesine bilgi sağlayan araştırma türüdür. Yakınsayan paralel desen; nitel ve nicel yöntemlere eşit önem vererek her iki aşamayı da süreçte eş zamanlı olarak uygulayıp çözümlerin ayrı ama yorumlamanın birlikte yapılmasıyla oluşan bir desendir (Creswell ve Plano Clark 2011). Bu çalışmada, "Ebeveyn Toplumsal Cinsiyet Gösterge Resimleri” ile "Cinsiyet Kalıp Yargı Ölçeği" kullanılarak çocukların ebeveynlerine yönelik ev içinde algıladıkları toplumsal cinsiyet rolleri ve kalıp yargıları araştırılmış, aynı zamanda çocuklarla bireysel görüşme yapılarak bu konudaki görüşleri derinlemesine incelenmiştir.

\section{Örneklem/Çalışma Grubu/Katılımcılar}

Araştırma grubu seçilirken amaçlı örneklem yöntemlerinden benzeşik örnekleme yöntemi kullanılmıştır. Amaçlı örnekleme, çalışmanın amacına bağlı olarak bilgi açısından zengin durumların derinlemesine araştırma yapılmasını sağlamaktadır (Büyüköztürk, Kılıç Çakmak, Akgün, Karadeniz ve Demirel, 2013). Benzeşik örneklemede ise amaç, küçük benzeşik bir örneklem oluşturma yoluyla belirgin bir alt grubu tanımlamaktır (Şimşek ve Yıldırım, 2013). Bu sebeple, bu araştırma için örneklem seçerken, belirlenen okul öncesi eğitim kurumlarına devam etmekte olan annesi çalışan ve çalışmayan beş yaş grubu çocuklar ile çalışmak hedeflenmiştir. Araştırmanın örneklemini belirleyen çocuklar, Ankara ilinde devlete bağlı bağımsız bir anaokulundaki gönüllü ailelerin gönüllü çocuklarıdır. Belirlenen anaokulunun idareci ve öğretmenlerine araştırmanın amacı, veri toplama süreçleri detaylı olarak anlatılarak çalışmaya destek olabileceğini belirten altı öğretmenin sınıfındaki beş yaş çocuklarının ailelerine araştırma ile ilgili tüm bilgilerin ve etik kuralların yazılı olduğu aydınlatılmıs onam formu gönderilmiştir. Ailelerinden onay alınan çocuklar araştırma amacında belirlenen demografik bilgilere göre gruplandırılmış ve minimum sayı olan sekiz baz alınarak diğer gruplardaki sekizden fazla olan çocuklar kura yöntemi ile seçilmiştir. Örneklem seçiminde çocukların cinsiyetleri de göz önünde bulundurularak, annesi çalışmakta olan 8 erkek, annesi çalışmakta olan 8 kız; annesi çalışmayan 8 erkek ve annesi çalışmayan $8 \mathrm{kız}$ çocuğu ile toplamda okul öncesi eğitime devam eden 32 çocuk ile çalışmak hedeflenmiştir.

\section{Veri Toplama Araçları}

Araştırmada veri toplama aracı olarak, araştırmacılar tarafından hazırlanan "Ebeveyn Toplumsal Cinsiyet Gösterge Resimleri”, "Yarı Yapılandırılmış Görüşme Soruları", “Ebeveyn Demografik Bilgi Formu" ve Şirvanlı Özen (1992) tarafından uyarlaması yapılmış olan "Cinsiyet Kalıp Yargı Ölçeği" kullanılmıştır.

Araştırmacılar tarafından hazırlanan veri toplama araçlarının oluşturulmasında, alan yazın referans alınmış olup, konu ile ilgili 3 alan uzmanından uzman görüşü alınmış, alınan kavramsal ve dilbilgisel düzeltmeler sonucunda veri toplama araçlarına son hal verilmiştir. 
Ebeveyn Toplumsal Cinsiyet Gösterge Resimleri, ebeveynlerin genellikle ev yaşantılarında kullandıkları ütü, elektrikli süpürge, çekiç/çivi, tencere gibi 25 maddeden oluşan nesneleri içermektedir. Çocuklarla birebir görüşmeler yapılarak, gösterilen nesneyi evde en çok kimin (anne, baba, anne ve baba, hiçbiri) kullandığı sorulmuştur. Verilen cevaplar not edilerek, çocukların nesneleri en çok kime ithaf ettiği hesaplanmıştır. Yarı yapılandırılmış görüşme soruları, ebeveynlerin evdeki iş bölümlerine yönelik (yemeği kim hazırlar, bir şey bozulduğunda kim tamir eder gibi) 8 sorudan oluşmaktadır. Görüşmeler çocuklarla birebir yapılmış olup, ses kayıt cihazı kullanılarak ses kaydı alınmıştır. Veriler tümevarımsal yaklaşım çerçevesinde çözümlenmiştir.

Cinsiyet Kalıp Yargı Ölçeği, Williams ve Bennett (1975) tarafından geliştirilmiş ve Şirvanlı Özen (1992) tarafından uyarlaması yapılmıştır. Ölçekte toplam bir iki cümleden oluşan 32 kısa hikâye ve bu hikâyeler için görseller bulunmaktadır. Ölçeğin güvenirlik testleri yapılmıştır. Test tekrar test güvenirliği katsayısı 0,74, iki yarım güvenirliği katsayısı 0,73 olarak belirlenmiştir.

\section{Verilerin Analizi}

Ebeveyn Toplumsal Cinsiyet Gösterge Formu ölçme aracının verileri, evde kullanılan tencere, tornavida/çivi, parfüm, elektrik süpürgesi, alışveriş arabası, televizyon, kitap gibi eşyalardan oluşan resimleri çocukların anne, baba ve ikisinin birlikte yer aldığı ebeveyn resimleriyle eşleştirmesi ve bu üç kategoriden elde edilen toplam puanın hesaplanması şeklinde toplanmiştır.

Yarı yapılandırılmış görüşme sorularının verileri araştırmacılar tarafından çocuklarla yüz yüze görüşme yaparak elde edilmiş olup, görüşmeler yaklaşık olarak 10 dakika sürmüştür. Görüşmeler okul içerisinde çocukların aşina oldukları kütüphane, uyku odası gibi sessiz mekânlarda yapılmıştır. Görüşmeler ebeveynlerin ve çocukların izinleri sonucunda ses kayıt cihazına kayıt edilmiştir. Araştırmanın örnekleminde belirlenen 32 çocuğun tamamına ulaşılana kadar okula gidilerek veri toplama süreci devam etmiştir. Ses kayıtları araştırmacılar tarafından transkript edilerek bu taranskriptler üzerinden veriler kod ve temalara ayrılmıştır. Araştırmacılar arası tutarlılığın sağlanması için veriler ayrı ayrı kodlara ayrılmış ortak belirlenmeyen kodlarda üç araştırmacı birlikte tartışarak sonuç ortaya çıkmıştır. Görüşme soruları "yemek pişirme, "masa hazırlama-toplama", "tamir", "alışveriş" olmak üzere dört alt boyuta ayrılarak gruplandırılmış olup her bir alt boyut da anne, baba, her ikisi şeklinde kodları içermektedir. Görüşme soruları çocuğun yaşı, kardeş sayısı gibi 1sındırma soruları ile başlayıp, beş adet görüşme sorusundan oluşmaktadır. Analiz esnasında "Yemekten önce masayı kim hazırlar?" ve "Yemekten sonra masayı kim toplar?" soruları bir kategoride toplanmışır. Araştırmanın amacına uygun sorulara yanıt bulabilmek adına nitel araştırma deseninden yarı yapılandırılmış görüşme tekniğinden yararlanılmıştır. Yarı yapılandırılmış görüşme tekniğinde görüşmenin akışına göre farklı yan ve alt sorularla görüşmenin akışı etkilenebilmekte ve katılımcıların yanıtlarını açmaları ve ayrıntılandırılmaları sağlanabilmektedir (Türnüklü, 2000).

Ebeveyn Demografik Bilgi Formu araştırmanın çalışma grubundaki çocukların ailelerine öğretmen aracılığıyla gönderilerek toplanmıştır.

Cinsiyet Kalıp Yargı Ölçeği yine araştırmacılar tarafından çocuklarla birebir ölçeğin resimleri gösterilip kısa hikâyelerin okunması ve çocuğun verdiği cevabın kodlanması şeklinde toplanmıştır. Ölçekte 32 adet kısa hikâye ve bu hikâyeler için kullanılan resimler çocuğa gösterilerek hikâyelerdeki sıfatları çocukların erkek ya da kadını göstermeleri şeklinde uygulanarak cevaplar puanlanmıştır. Toplanan tüm veriler SPSS 20 programılla uygun şekilde 
sayısal verilere dökülerek grilmiş ve tümevarımsal betimsel analiz ve çapraz tablo analizi ile analiz edilmiştir. Yakınsayan Paralel Desen, araştırmacının nitel ve nicel verileri birlikte topladığ ancak analizlerini ayrı ayrı yaptığı ve bulguların birbirini doğrulayıp doğrulamadığına baktığı desendir. Tümevarımsal yaklaşımda ortaya çıkan kod- tema ve örüntülerden yola çıkılarak durumlar ortaya konurken, tümdengelimsel analiz yaklaşımında değişkenler arasında beklenen ilişkiler önceden belirlenmektedir (Patton, 2004).

\section{BULGULAR}

$\mathrm{Bu}$ bölümde araştırmanın alt problemlerine ilişkin bulgular tablolaştırılarak yorumlanmıştır.

Tablo 1. Anne çalışma durumuna göre ebeveyn toplumsal cinsiyet göstergesi

\begin{tabular}{lccc}
\hline & Çalışıor (f) & Çalışmıor (f) & Toplam (f) \\
\hline Anne & 3 & 6 & 9 \\
Baba & 4 & 3 & 7 \\
Her ikisi & 9 & 7 & 16 \\
Toplam & 16 & 16 & 32 \\
\hline
\end{tabular}

Tablo 1'de görüldüğü üzere Ebeveyn Toplumsal Cinsiyet Gösterge Resimleri'ni annesi çalışan 16 çocuktan 3'ü anneyle, 4' ü babayla, 9'u ise her ikisi ile eşleştirmiştir, annesi çalışmayan 16 çocuktan ise 6 'sı anneyle, 3'ü babayla, $7^{\prime}$ si de her ikisi ile eşleştirmiştir.

Tablo 2. Cinsiyete göre ebeveyn toplumsal cinsiyet göstergesi

\begin{tabular}{lccc}
\hline & Kiz (f) & Erkek (f) & Toplam (f) \\
\hline Anne & 5 & 4 & 9 \\
Baba & 4 & 3 & 7 \\
Her ikisi & 7 & 9 & 16 \\
Toplam & 16 & 16 & 32 \\
\hline
\end{tabular}

Tablo 2'ye göre Ebeveyn Toplumsal Cinsiyet Gösterge Resimleri'ni kız çocuklarının 5'i anneyle, 4'ü babayla, $7^{\prime}$ si her iki ebeveyn ile eşleştirmiş, erkek çocuklarının 4'ü anneyle, 3'ü babayla, 9'u her ikisiyle eşleştirmiştir.

Tablo 3. Anne çalışma durumuna göre cinsiyet kalıp yargı durumları

\begin{tabular}{lccc}
\hline & Çalışan (f) & Çalışmayan $(\mathrm{f})$ & Toplam $(\mathrm{f})$ \\
\hline Var & 13 & 14 & 27 \\
Yok & 3 & 2 & 5 \\
Toplam & 16 & 16 & 32 \\
\hline
\end{tabular}

Tablo 3'te görüldüğ ü üzere kalıp yargısı olmayan 5 çocuktan 3'ünün annesi çalışmakta, 2'sinin annesi çalışmamakta, kalıp yargısı bulunan 27 çocuktan 13'ünün annesi çalışmakta, 14'ünün annesi çalışmamaktadır.

Tablo 4. Cinsiyete göre cinsiyet kalıp yargı durumları

\begin{tabular}{lccc}
\hline & Kiz (f) & Erkek (f) & Toplam (f) \\
\hline Var & 15 & 12 & 27 \\
Yok & 1 & 4 & 5 \\
Toplam & 16 & 16 & 32 \\
\hline
\end{tabular}

Tablo 4 'de görüldügü üzere kız çocuklarının 1'inin kalıp yargısı yokken 15'inin kalıp yargısı bulunmakta, erkek çocuklarının 4'ünün kalıp yargısı yokken 12 'sinin kalıp yargısı bulunmaktadir. 
Tablo 5. Cinsiyet kalıp yarg1 durumuna göre ebeveyn toplumsal cinsiyet göstergesi

\begin{tabular}{lccc}
\hline & Yok (f) & Var (f) & Toplam (f) \\
\hline Anne & 1 & 8 & 9 \\
Baba & 2 & 5 & 7 \\
Her ikisi & 2 & 14 & 16 \\
Toplam & 5 & 27 & 32 \\
\hline
\end{tabular}

Tablo 5 'te görüldüğü üzere cinsiyet kalıp yargısı bulunan 5 çocuktan 2'si resimleri babayla, 2' si her ikisiyle ve 1'i anneyle eşleştirmiş; kalıp yargısı olmayan 27 çocuktan ise $14^{\prime}$ ü her ikisiyle 8'i anneyle 5'i babayla eşleştirmiştir.

Tablo 6. Anne çalışma durumu ve cinsiyete göre cinsiyet kalıp yargısı olan ve olmayan çocukların ebeveyn toplumsal cinsiyet gösterge resimlerini eşleştirme durumu

\begin{tabular}{cccccccc}
\hline & \multicolumn{2}{c}{ Anne } & \multicolumn{2}{c}{ Baba } & \multicolumn{2}{c}{ Birlikte } \\
\hline \multicolumn{2}{c}{ Cinsiyet Kalıp Yargı } & Var & Yok & Var & Yok & Var & Yok \\
\hline Çalışan Anne (16) & Kız (8) & 1 & 0 & 2 & 1 & 4 & 0 \\
& Erkek (8) & 0 & 1 & 0 & 1 & 5 & 1 \\
\hline Çalışmayan Anne & Kız (8) & 4 & 0 & 1 & 0 & 2 & 1 \\
(16) & Erkek (8) & 3 & 0 & 2 & 0 & 2 & 1 \\
\hline
\end{tabular}

Tablo 6'da görüldüğgü üzere annesi çalışan 8 kız çocuğundan ebeveyn toplumsal cinsiyet gösterge resimlerini anne ile eşleştiren 1 çocuğun cinsiyet kalıp yargısı bulunurken, baba ile eşleştiren 3 kız çocuğundan 2'sinin cinsiyet kalıp yargısı bulunmakta, 1 inin cinsiyet kalıp yargısı bulunmamakta, anne ve baba birlikte eşleştiren annesi çalışan $4 \mathrm{kız}$ çocuğunun tamamının cinsiyet kalıp yargısı bulunmaktadır.

Annesi çalışan 8 erkek çocuğundan ebeveyn toplumsal cinsiyet gösterge resimlerini anne ile eşleştiren 1 çocuğun cinsiyet kalıp yargısı bulunmazken benzer şekilde baba ile eşleştiren 1 çocuğun da cinsiyet kalıp yargısı bulunmamaktadır. Anne ve baba birlikte eşleştiren annesi çalışan 6 erkek çocuktan 5'inin cinsiyet kalıp yargısı bulunurken, 1'inin cinsiyet kalıp yargısı bulunmamaktadır.

Annesi çalışmayan $8 \mathrm{k}$ z çocuğundan ebeveyn toplumsal cinsiyet gösterge resimlerini anne ile eşleştiren 4, baba ile eşleştiren 1 , anne ve baba birlikte eşleştiren 2 kız çocuğunun cinsiyet kalıp yargısı bulunurken, anne ve baba birlikte eşleştiren $1 \mathrm{kız}$ çocuğunun cinsiyet kalıp yargısı bulunmamaktadır.

Annesi çalışmayan 8 erkek çocuğundan ebeveyn toplumsal cinsiyet gösterge resimlerini anne ile eşleştiren 3, baba ile eşleştiren 2 ve anne baba birlikte eşleştiren 2 çocuğun cinsiyet kalıp yargısı bulunurken anne ve baba ile birlikte eşleştiren annesi çalışmayan 1 erkek çocuğunun cinsiyet kalıp yargısı olmadığı bulunmuştur. 
Tablo 7. Cinsiyet kalıp yargı durumuna göre görüşme cevapları

\begin{tabular}{llccc}
\hline & & Var (f) & Yok (f) & Toplam (f) \\
\hline \multirow{3}{*}{ Yemek Pişirme } & & & & \\
& Anne & 17 & 3 & 20 \\
\multirow{5}{*}{ Masa Hazırlama } & Baba & 0 & 0 & 0 \\
& İkisi Birlikte & 10 & 2 & 12 \\
\cline { 2 - 5 } Tamir & Anne & 17 & 4 & 21 \\
& Baba & 3 & 0 & 3 \\
& İkisi Birlikte & 7 & 1 & 8 \\
\cline { 2 - 5 } Alı̧veriş & Anne & 0 & 0 & 0 \\
& Baba & 23 & 4 & 27 \\
& İkisi Birlikte & 4 & 1 & 5 \\
\cline { 2 - 5 } & Anne & 8 & 0 & 2 \\
\hline
\end{tabular}

Tablo 7'de görüldüğü üzere cinsiyet kalıp yargısı olan 27 çocuktan; yemek pişirme alt boyutu için 17'si anne, 10'u her ikisi eşleştirmesi yapmış; masa hazırlama ve toplama alt boyutu için $17^{\prime}$ 'si anne, $7^{\prime}$ si her ikisi, 3'ü baba eşleştirmesi yapmış; tamir alt boyutu için $23^{\prime}$ ü baba, 4' ü ikisi birlikte eşleştirmesi yapmış; alışveriş alt boyutu için 17'si ikisi birlikte, 8'i anne 2'si baba eşleştirmesi yapmıştır. Cinsiyet kalıp yargısı olmayan 5 çocuktan; yemek pişirme alt boyutu için 3'ü anne, 2'si baba ve hiçbiri ikisi birlikte eşleştirmesi yapmış; masa hazırlama ve toplama alt boyutu için $4^{\prime} \ddot{u}$ anne, 1'i her ikisi, hiçbiri baba eşleştirmesi yapmış; tamir alt boyutu için 4'ü baba, 1'i ikisi birlikte, hiçbiri anne eşleştirmesi yapmış; alışveriş alt boyutu için 5'i her ikisi, hiçbiri anne ve baba eşleştirmesi yapmıştır.

\section{Çocukların Gözünden Evdeki İşlerin Dağılımına İlişkin Nitel Araştırma Bulguları}

Ebeveynlerin evdeki işleri paylaşmalarına yönelik çocuklarla yapılan görüşmelerde, yemek yapma, masayı hazırlama, tamir, alışverişe gitme gibi konulara yer verilmiştir.

Evde yemeği kim yapıyor sorusuna, 'annem' yanıtının en fazla verilen yanıt olduğu görülmektedir. Ancak evde yemeği genel olarak annenin yaptığı vurgulansa da, babanın da zaman zaman anneye yardım ettiği görülmektedir. Genel olarak ailelerde beslenme işinin anneye ait olduğu görülmektedir.

'Zorları ikisi birlikte, kolayları annem yapıyor.' (Kod 14 - Çalışan - E)

'Annem. Babam bazen yemek yapıyor.' (Kod 8 - Çalışan- K)

Evde yemek yemeden önce masayı kim hazırlıyor ve yemekten sonra masayı kim topluyor sorularına, verilen yanıtların büyük bir çoğunluğunda 'annenin' bu süreçte yer aldığı görülmektedir. Ancak bu süreçte babanın da yer aldığı vurgusu bazı çocuklar tarafından yapılmıştır.

'Annem tek başına topluyor. Ben bazen yardım ediyorum. Babam televizyon izliyor.' (Kod 7 Çalışmayan - E)

'Annem ve babam topluyorlar. Ben televizyon izliyorum.' (Kod 5 - Çalışan - K)

'Ben, abim ve babam hazırlyyor.' (Kod 13 - Çalışan - E)

'Annem ve babam birlikte.' (Kod 24 - Çalışmayan - K)

Evde bir şey bozulduğunda kim tamir ediyor sorusuna 'babam' yanıtının en fazla verilen yanıt olduğu görülmektedir. Evde tamir işlerini babanın yaptığı vurgulansa da zaman zaman 
tamirciye ihtiyaç duyulduğu görülmektedir. Araştırmaya katılan çocukların cevapları incelendiğinde güç gerektiren ve anlık yapılacak işlerde babanın ön planda olduğu bulgusuna rastlanmıştır.

'Babam ya da tamirci.' (Kod 16 - Çalışan - E)

'Tamirci.' (Kod 2 - Çalışmayan - E)

Kiminle beraber alışverişe gidiyorsun ve oyuncaklarını, kıyafetleri kim satın alıyor sorularına 'her iki ebeveyn' yanıtının en fazla verilen yanıt olduğu görülmektedir.

'Yengem, annem, kardeşim ve ben birlikte gidiyoruz. Oyuncaklarımı ve kıyafetlerimi annem alıyor.' (Kod 23 - Çalışmayan - K)

'Babam ve annem birlikte gidiyoruz. İkisi de alıyor.' (Kod 9 - Çalışan - K)

'Annem ile babam, bazenleri ablam da geliyor. Oyuncaklar babam alıyor, kıyafetleri annem de babam da alıyor.' (Kod 29 - Çalışmayan - E)

'Alışverişe ailecek gidiyoruz ama annem alıyor.' (Kod 21 - Çalışan - E)

$\mathrm{Bu}$ araştırmanın nitel bulgularından açıkça görülmektedir ki aile yapısı ve aile içi sorumluluk bağlamında, kadın ve erkek toplumsal cinsiyet rollerine uygun görevler üstlenmektedir.

\section{TARTIŞMA, SONUÇ VE ÖNERILLER}

Araştırmadan elde edilen sonuçlar doğrultusunda anne çalışma durumu ve çocukların cinsiyetleri, evdeki eşyaları ebeveynlerden hangisinin daha çok kullandığı bulgusunu değiştirmemektedir. Bulgulara paralel olarak, Şirvanlı Özen (1992), tarafından yapılan araştırmada da annenin çalışıp çalışmama durumunun cinsiyet özelliklerine ilişkin kalıp yargılar üzerinde etkili olmadığı sonucuna ulaşılmıştır. 2001 yılı Aile Raporu'nda ise yapılan araştırmalar sonucunda kadının eğitim düzeyi, evlilik süresi, kadının çalışma oranı, ailedeki kişi sayısı arttıkça ve kırdan kente gidildikçe sorumluluk dağılımı ve evle ilgili faaliyetlerde işbirliğine doğru bir yönelme olduğu görülmüştür (2001 Yılı Aile Raporu, 2002). Fakat 1986 yılında Eren tarafından yapılan araştırmada annesi devamlı çalışan çocukların, annesi aralıklarla çalışan ya da hiç çalışmayan çocuklara oranla daha az cinsiyete ilişkin kalıp yargılara sahip oldukları gözlenmiştir. Çalışmamızda ebeveyn toplumsal cinsiyet göstergesini belirlemeye yönelik kullanılan resimlerin her iki cinsiyetin kullandığı eşyaların resimlerinin seçilmesi, annesi çalışan çocuklarında annesi çalışmayan çocuklarında çoğunluğunun evdeki eşyaları her iki ebeveyninde kullandığını belirtmiş olmasının bir sebebi olmasına karşın, görüşme sorularında elde edilen sonuçlarda çocuğun kalıp yargı düzeyine bakılmaksızın yemek pişirme, masa hazırlama ve toplama gibi mutfak işlerinde annelerin daha aktif rol aldığı, tamir işlerinde babaların daha aktif rol aldığı ve alışveriş işlerinde her iki ebeveynin de aktif rol aldığı görülmektedir. Çalışmanın bu verileri, Türk İstatistik Kurumu (2016) tarafından yapılan Aile Yapısı Araştırma'sının verileri ile uyumludur. Ülke çapında yapılan araştırmalar sonucunda temizlik, yemek pişirme, ayarlama ve temizlik gibi işler \%91,3 oranında anneler tarafından yapılmaktadır. Ayrıca aynı araştırmada, babaların \%45.5'inin ve annelerin \%54.5'inin alışveriş etkinliğine katıldığı sonucu, çocukların görüşme sorularında verdikleri alışverişe her iki ebeveynin de katıldığı sonucuyla paralellik göstermektedir. Toplumsal cinsiyet rollerine ilişkin bakış açısında, Türkiye' de kadının ve erkeğin ev içi rolleri geleneksel aile yapısında daha çok görevler ve sorumluluklar temelinde kurulmakta, 
erkek evin ekmeğini kazanmakla ve ailesinin geçimini sağlamakla yükümlüyken, kadın annelik, bakım ve beslenme gibi temel ev içi faaliyetlerden sorumludur (Kandiyoti, 1988).

Çocukların cinsiyeti ile çocukların kalıp yargı düzeyleri arasında bir farklılık bulunmamıştır. Şirvanlı-Özen (1992)'in çalışmasında cinsiyet özelliklerine ilişkin kalıp yargılarda kızlar ve erkekler arasında herhangi bir farklılık göstermemektedir. Çalışmaların çoğunda cinsiyet özelliklerinin kalıp yargı bilgisinde erkek ve kız çocukları arasında hiçbir fark olmadığı bildirilmiştir (Williams, Bennett ve Best, 1975; Williams, Best, Haque, Pandley ve Verma, 1982; Eren, 1986; Ward, 1990; Kahraman ve Başal, 2011). Cinsiyete göre kalıp yargıda değişiklik olmayışı çocukların yaşlarına uygun gelişimsel özellik göstererek çevrelerindeki gözlemlerini benzer şekilde yorumlamalarından kaynaklanabilir. Fakat Best, Williams, Cloud, Davis, Robertson ve Edwards (1997) tarafından Amerika, İngiltere ve İrlanda'da çocuklarla yapılan çalı̧̧mada, erkek çocuklarının erkek özelliklerine ilişkin toplumsal cinsiyet kalıp yargılarının, kadın özelliklerine ilişkin kalıp yargılardan daha fazla farkında oldukları bulunmuştur. Bu bulgu cinsiyet kalıp yargısının kadın ve erkek özelliklerine ilişkin kalıp yargıların detaylı bir şeklinde incelemesi yapıldığında farklı sonuçların çıkabileceğini göstermektedir.

Araştırmada elde edilen önemli bir bulgu, anne çalışma durumu ile çocukların kalıp yargı düzeyleri arasında anlamlı bir farklılık bulunmamasıdır. Anne çalışma durumuna göre ev içi rollerin değişebileceği varsayımından yola çıkarak örneklemin belirlendiği bu çalışmada ortaya çıkan bu sonucun ülkemizin toplumsal ataerkil yapısından kaynaklandığı düşünülmektedir. Benzer şekilde Türkiye İstatistik Kurumu tarafından yürütülen araştırmanın sonucu olarak, çalışan anneler, hane halkı ve aile bakımı faaliyetleri için 211 dakika harcadığı halde, babalar sadece 46 dakika harcıyorlar (TUIK, 2015).

Cinsiyet kalıp yargı puanlarına göre ebeveyn toplumsal cinsiyet göstergeleri incelendiğinde ve resimleri "her ikisi" ile eşleştirenlerin sayısının fazla olması göz önünde bulundurulduğunda, kalıp yargının çocukların evdeki eşya kullanımına ilişkin eşleştirmelerinde bir farklılık bulunmadığı görülmektedir. Ancak kalıp yargısı olmayan çocukların hem "her ikisi" hem de "baba" puanları eşit olarak en yüksek puan iken kalıp yargısı bulunan çocuklarda baba puanın en düşük puan olması da önemli bir sonuç olarak değerlendirilmelidir. Başka bir deyişle genel olarak ülkemizde ev ile ilgili sorumlukların çoğunlukla kadına ya da iyi ihtimal hem kadın hem erkeğe yüklenilmesine karşın kalıp yargısı olmayan çocukların bu sorumluluğu sadece babaya ya da hem anne hem babaya yüklemekte bir sakınca görmemesidir.

Araştırma sonucunda, araştırmaya katılan 32 çocuktan Cinsiyet Kalıp Yyargı Ölçeği'ne göre 27'sinin cinsiyet kalıp yargısı bulunmaktadır. Bu sonuç erken çocukluk döneminde cinsiyet kalıp yargılarına yönelik yapılan araştırma ve eğitimlerin sayısının artırılması gerektiğini şeklinde yorumlanabilir.

Çalışmada ev içi etkinliklerde anne babaların cinsiyet rollerine yönelik farklı uygulamalar olsa da çocukların bu durumu toplumsal cinsiyet temelinde ele aldıklarını görmek mümkündür. Ayrıca annenin iş yaşamında etkin bir şekilde yer alıp almaması ile çocukların sahip oldukları kalıp yargıları arasında doğrudan bir ilişki saptanmamıştır. Son olarak çalışmada beş yaş çocuklarda cinsiyete yönelik kalıp yargıların oluştuğu ve bu kalıp yargıların toplumsal cinsiyet rolleri ile doğrudan ilişkili olduğu gözlenmiştir.

$\mathrm{Bu}$ araştırmada araştırma grubu 32 beş yaş çocuğundan oluşmaktadır. Sonraki araştırmalar daha geniş örneklemlerle yapılabilir. Çocuğun ev ortamının yanı sıra, günlük 
yaşamda kullandığı eşyalar, oyuncaklar gibi çocuğun yakın çevresi değerlendirilerek araştırmalar daha kapsamlı bir şekilde yürütülebilir. Ayrıca boylamsal çalışmalar yapılarak çocuğun yaşı ve toplumsal cinsiyet rolleri ilişkisi incelenebilir. Çocuğun ev ortamı doğal gözlemler aracılığı ile gözlemlenerek ebeveynlerin ev içi rolleri hakkında daha detaylı araştırmalar yürütülebilir. Farklı ölçme araçları ile ebeveynlerin cinsiyet rolleri incelenerek, çocuklardaki toplumsal cinsiyet yansımaları incelenebilir. Çocukların toplumsal cinsiyet kalıp yargılarını ölçen farklı ölçme araçları geliştirmeye yönelik çalışmalar yapılabilir. Çocukların kalıp yargılarının oluşumunda ailenin rolüne ilişkin bu ölçme araçlarının da kullanılacağı karma yöntemde planlanmış araştırmalar yapılabilir.

\section{KAYNAKÇA}

Baran, G. (1995). Ankara'da bulunan çocuk yuvalarında kalan 7-11 yaş grubu çocuklarda cinsiyet rolleri ve cinsiyet özellikleri kalıpyargılarının gelişimi. Yayınlanmamış Doktora Tezi, Ankara Üniversitesi, Ankara.

Başal, H. A. (2004). Anababa yoksunluğunun çocukların cinsiyet özelliklerine ilişkin kalıpyargılarının ve cinsiyet kimliklerinin gelişimleri üzerine etkisi. XII. Eğitim Kongresi Bildiriler (Cilt II), Ankara: Gazi Üniversitesi Eğitim Bilimleri Enstitüsü, 827-852.

Bayramoğlu, L. (2015). Okul öncesi dönem çocuklarının cinsiyet rollerine ilişkin algılarının incelenmesi. Yayınlanmamış Yüksek Lisans Tezi, Doğu Akdeniz Üniversitesi, Gazimağusa, Kuzey Kibris.

Berk, L. E. (2015). Tarih, teori ve araştırma stratejisi. (N. Işıkoğlu Erdoğan, Çev. Ed.). Bebekler ve çocuklar doğum öncesinden orta çocukluğa (ss. 2-49). Ankara: Nobel. (Orijinal çalışmanın yayın tarihi 2012).

Best, D. L., Williams, J. E., Cloud, J. M., Davis, S. W., Robertson, L. S., Edwards, J. R., Giles, H., \& Fowles, J. (1977). Development of sex-trait stereptypes among young children in United States, England and Ireland. Child Development, 48, 1375-1384.

Birey, T., \& Beyidoğlu Önen, M. (2013). Toplumsal cinsiyet ve öğretmenlik: Öğretmenlerin bakış açısı. Lefkoşa: POST.

Büyüköztürk, Ş., Kılıç Çakmak, E., Akgün, Ö. E., Karadeniz, Ş., \& Demirel, F. (2013). Bilimsel araştırma yöntemleri. (15. Baskı). Ankara: Pegem Yayıncılık.

Creswell, J. W., \& Plano Clark V.L. (2011). Karma yöntem araştırmalarının doğası. (Y. Dede, S. B. Demir Çev. Ed.). Karma yöntem araştırmaları: tasarımı ve yürütülmesi (ss.1-22). Ankara: Anı. (Orijinal çalışmanın yayın tarihi 2011).

Dilek, Y. (1997). Parents role in preschool childrens gender role socialization. Yayınlanmamı̧̧ Yüksek Lisans Tezi, Orta Doğu Teknik Üniversitesi, Ankara.

Dökmen, Z. Y. (2012). Toplumsal cinsiyet (3. Baskı). İstanbul: Remzi Kitapevi.

Eren, A. (1986). Sex role and sex trait stereotypes in children. Yayınlanmamış Yüksek Lisans Tezi, Orta Doğu Teknik Üniversitesi Sosyal Bilimler Enstitüsü, Ankara.

Esmer, Y. (2012). Türkiye değerler atlası. Erişim bağlantısı ve tarihi:: https://www.academia.edu/people/search?utf8=\%E2\%9C\%93\&q=t\%C3\%BCrkiye+de $\%$ C4\%9Ferler+atlas\%C4\%B1 , 12.08.2017.

Güldü, Ö., \& Ersoy-Kart, M. (2009). Toplumsal cinsiyet rolleri ve siyasal tutumlar, Ankara Üniversitesi SBF Dergisi, 64(3), 97-116.

Gümüşoğlu, F. (2004). İlköğretim öğrencilerinin toplumsal cinsiyet algıları, kadın çalışmalarında disiplinler arası buluşma, 3, 317-327, İstanbul: Yeditepe Üniversitesi Yayınları. 
Inglehart, R., \& Norris, P. (2003). Rising tide: Gender equality and cultural change around the world. Cambridge: Cambridge University Press.

Kahraman, P. B., \& Başal, H. A. (2011). Anne eğitim düzeyine göre çocukların cinsiyet kalıp yargiları ile oyun ve oyuncak tercihleri. Education Sciences, 6(1). S. 1335-1357.

Kandiyoti, D. (1988). Bargaining with patriachy. Gender and Society, 2(3), 274-290.

Martin, C. L., \& Ruble, D. (2004). Children search for gender cues: cognitive perspectives on gender development. Current Directions in Psychological Science, 13(2), 67-70.

Şafak, Ş. Çopur, Z., \& Özkan, M. (2006). Çocukların evle ilgili faaliyetlere harcadıkları zamanın incelenmesi. Erişim bağlantısı ve tarihi: http://www.sdergi.hacettepe.edu.tr/makaleler/sszcmao.pdf., 21.09.2017.

Şirvanl1-Özen, D. (1992). Annenin çalısma durumu ve ebeveynin benimsediği cinsiyet rolü değiş̧kenlerinin çocuğun cinsiyet özelliklerine ilişkin kalıpyargılarının gelişimi üzerindeki rolü Yayınlanmamış Yüksek Lisans Tezi, Hacettepe Üniversitesi, Ankara.

Terzioğlu, F., \& Taşkın, L. (2008). Kadının toplumsal cinsiyet rolünün liderlik davranışlarına ve hemşirelik mesleğine yansımaları. Cumhuriyet Üniversitesi Hemşirelik Yüksekokulu Dergisi, 12(2), 62-67.

TUIK (2016). Zaman kullanımı araştırması. Erişim bağlantısı ve tarihi: http:/ / www.tuik.gov.tr/PreTablo.do?alt_id=1068, 29 Mayıs 2017.

TUIK (2016). Aile yapısı araştırması. Erişim bağlantısı ve tarihi: http:/ / www.tuik.gov.tr/PreTablo.do?alt_id=1068, 29 Mayıs 2017.

Türnüklü, A. (2000). Eğitimbilim araştırmalarında etkin olarak kullanılabilecek nitel bir araştırma tekniği: Görüşme. Kuram ve Uygulamada Eğitim Yönetimi, 24, 543.

Yağan Güder, S., \& Güler Yıldız, T. (2016). Okul öncesi dönemdeki çocukların toplumsal cinsiyet algılarında ailenin rolü. Hacettepe Üniversitesi Eğitim Fakültesi Dergisi, 31(2), 424-446.

Yeşilyaprak, B. (2015). Eğitim psikolojisi: Gelişim-öğrenme-öğretim (14. Baskı). Ankara: Pegem Akademi.

Yıldırım, A., \& Şimşek, H. (2013) Sosyal bilimlerde nitel araştırma yöntemleri. (9. Baskı). Ankara: Seçkin Yayınevi.

Ward, C. (1990). Gender stereotyping in Singaporean children. International Journal of Behavioral Development, 13, 309-311.

Williams, J. E., \& Bennett, S. M. (1975). Awareness and expression of sex stereotypes in young children. Developmental Psychology, 11, 633-642.

Williams, J. E., \& Best, D. L. (1982). Measuring sex stereotypes: A thirty nation study. Becerly Hills, Calif: Sage.

2001 Yılı Aile Raporu (2002). (Ed. Çaylığlu, İ.) Aile İçi İlişkiler Komisyonu. 3. Ailede rol ve sorumluluklar. T.C. Başbakanlık Aile Araştırma Kurumu Yayınları, Yayın No:120. Ankara. Beyda Ofset. (ISBN 975-19-3235-1). 